\title{
NOVA2 wt Allele
}

National Cancer Institute

\section{Source}

National Cancer Institute. NOVA2 wt Allele. NCI Thesaurus. Code C51291.

Human NOVA2 wild-type allele is located in the vicinity of 19q13.3 and is approximately $34 \mathrm{~kb}$ in length. This allele, which encodes RNA-binding protein Nova-2, plays a role in the regulation of RNA splicing or metabolism in a specific population of developing neurons. 